\title{
Assessment of greenhouse gas emissions in building construction: A case study of SWC building at Kuet in Bangladesh
}

\author{
S. Anowar ${ }^{\text {iD }}$, F.H. Rakib*iD, R. Hasan ${ }^{\text {iD }}$, M. Rahman iD \\ Khulna University of Engineering and Technology, Department of Building Engineering and Construction \\ Management (BECM), Khulna, Bangladesh
}

\begin{abstract}
Being one of the primary contributors to global GHG emissions, the construction industry has been the focus of many recent studies. The process of manufacturing and transporting of building materials, and installing and constructing of buildings consumes great energy and emits a large quantity of greenhouse gas. This study identifies the sources of GHG emissions during building construction phase and estimates the GHG emissions from those sources for a case building in Bangladesh, following the process-based methodology. The results for the case building show that about $98.38 \%$ of total emissions are due to the manufacture and transportation of building materials, $1.31 \%$ is due to energy consumption during the construction period and only $0.31 \%$ are due to waste disposals, while concrete and brick-works are the most contributing materials to the GHG emissions, about $35.22 \%$ and $48.67 \%$ respectively. This study has been conducted in Bangladesh as the concern for GHG emissions in building construction is not satisfactory here yet. It also proposes a set of unique strategies, such as, using recycled building materials, especially recycled steel, as well as, transporting building materials by sea, re-using wooden waste materials and using hardwood plywood in place of non-load bearing brick walls and demonstrates the reduction of GHG emission numerically by applying these strategies, which are the originalities of this study.
\end{abstract}

\section{Keywords}

GHG emissions; Recycled materials; Transportation; Energy consumption; Environment

Received: 11 November 2019; Accepted: 26 December 2019

ISSN: 2630-5771 (online) C 2019 Golden Light Publishing All rights reserved.

\section{Introduction}

Buildings are considered to be responsible for playing a significant role to the environment, as it contributes more than one-third of global greenhouse gas (GHG) emissions (United Nations Environment Programme, UNEP). The emissions occur throughout the total life span of the building, including the manufacturing process of materials, construction procedure, operation and maintenance stages to end of life. The construction industry is also the largest consumer of resources and raw materials. As indicated by information from the World watch Institute, the construction of buildings every year consumes $40 \%$ of the stone, gravel and sand, $25 \%$ of the timber and $16 \%$ of the water on the world [1]. During the construction phase of a building, production of materials and transportation of building materials and energy consumption by construction processes emits a large amount of greenhouse gases (GHGs). A report by the Intergovernmental Panel on Climate Change (IPCC), 2018 shows that building sector was

\footnotetext{
Corresponding author

Email: mfhrakib78@gmail.com
} 
responsible for $36 \%$ of global final energy consumption and nearly $40 \%$ of total direct and indirect $\mathrm{CO}_{2}$ emissions and contributed about $25 \%$ of the total global greenhouse gas emissions, and the emission was increased at an average of $2.7 \%$ per year from 1999 to 2004 [2].

Due to the long-term life cycle and various types of activities, the construction industry clearly impacts negatively on the environment and hampers environmental sustainability. For example, transportation, construction machinery, waste production and energy consumption during building construction phase, have significant environmental costs, indicating that any improvements in these parts could be priority marks for reducing GHG emissions during the construction phase, as well as the overall life cycle impact of a building. [3] shows that the construction stage accounts for $20-30 \%$ of the initial embodied emissions and $6-10 \%$ of the total emissions of the life cycle stages of buildings.

Emissions from waste production can be reduced by recycling them and also by using compost masses and worm-farms to fertilize plants that can consume $\mathrm{CO}_{2}$ and even help to produce food [4]. Concrete, bricks, sand, cement, glass, wood etc. are typically used for building construction in Bangladesh, where all the materials used for construction of a building has a negative impact on the environment as they all are responsible for contributing to the global GHG emissions, except wood. Wood-based products store carbon in their structure throughout their life cycle periods. As a result, continuous replantation and harvesting activity allows capturing an increasing quantity of carbon from the air [5]. Even if disposed of in landfills, most of the carbon remains stored in them for many decades.

Previously many studies have been performed on energy use and GHG emissions in the building life cycle or operating and maintenance phase, but only a few focused on the construction phase of buildings. This paper focuses on all the major sources of GHG emissions in building construction phase from the manufacture or production of the building materials to the handling of the construction wastes over the construction period. In this paper, it is also intended to establish a calculation method for all the major sources of GHG emissions in building construction and to implement it to a practical case building in Bangladesh. The explicit objectives of this paper are: (i) to define the scope and identify the sources of GHG emissions in building construction and establish equations for calculating GHG emissions within the scope; (ii) to calculate the GHG emissions of identified sources in constructions of the practical case building, i.e. SWC building; and (iii) to analyse the results calculated by the established method, and propose recommendations on how the emissions could be reduced for that particular building.

\section{Literature review}

\subsection{Greenhouse gases (GHG)}

A greenhouse gas is a gas that absorbs and releases radiant energy within the thermal infrared range. The more of these gases that exist, the more heat is prevented from escaping into space and, therefore, the more the earth heats. This rise in heat is called the greenhouse effect. Several gases contribute to the greenhouse effect that outlines global temperature over a geologic period. Minor changes in the atmospheric concentration of these gases can lead to changes in temperature. The leading greenhouse gases in the global atmosphere are as follows: carbon dioxide, methane, nitrous oxide, ozone, water vapor, sulfur hexafluoride, chlorofluorocarbons and hydrofluorocarbons. Every greenhouse gas (GHG) incorporates a completely different global warming potential (GWP) and persists for a unique time period in the atmosphere. The three major greenhouse gases, along with water vapor and their global warming potential (GWP) compared to carbon dioxide are like this: GWP $=1$ for carbon dioxide $\left(\mathrm{CO}_{2}\right)$, GWP $=25$ for methane $\left(\mathrm{CH}_{4}\right)$ i.e. discharging $1 \mathrm{~kg}$ of $\mathrm{CH}_{4}$ into the atmosphere is about equivalent to releasing $25 \mathrm{~kg}$ of $\mathrm{CO}_{2}$ and $\mathrm{GWP}=298$ for nitrous oxide $\left(\mathrm{N}_{2} \mathrm{O}\right)$ i.e. discharging $1 \mathrm{~kg}$ of $\mathrm{N}_{2} \mathrm{O}$ into the atmosphere is about equivalent to releasing $298 \mathrm{~kg}$ 
of $\mathrm{CO}_{2}\left(\mathrm{CO}_{2}\right.$ Equivalents and 100-year GWP, Climate Change Connection).

Among them, water vapor is not considered to be a reason for man-made global warming since it perseveres in the atmosphere for not more than a few days. There are other greenhouse gases that have far greater global warming potential (GWP) but are much less predominant. For example, sulfur hexafluoride $\left(\mathrm{SF}_{6}\right)$, hydrofluorocarbons (HFCs), and perfluorocarbons (PFCs) are those less predominant greenhouse gases (GHG). There is an extensive diversity of uses for $\mathrm{SF}_{6}$, HFCs, and PFCs but they have been most frequently used as refrigerants and for fire suppression. These compounds also have a diminishing effect on ozone in the upper atmosphere. As the contributing portions of water vapor, sulfur hexafluoride, chlorofluorocarbons and hydrofluorocarbons are negligible comparing to the others, this paper only focuses on three types of gases- carbon dioxide, methane and nitrous oxide.

\subsection{Sources of GHG Emissions}

A number of papers were reviewed containing the terms "Greenhouse gas emission" or " $\mathrm{CO}_{2}$ emission or carbon dioxide emission" or "building construction". Most of the findings were related to the calculation of $\mathrm{CO}_{2}$ emissions of buildings over its life cycle period. Only a few findings were related to the construction stage of buildings. 24 studies were found and studied that involved the construction stages for estimating GHG emissions. For example, Yan et al. 2010 abridged four major emission sources on construction sites, i.e. building materials production and transportation, energy use of construction equipment, energy use for processing resources, and disposal of construction waste [6]. Following these 24 studies, three major sources for GHG emissions were identified which are summarized as follows: (1) manufacture and transportation of building materials; (2) energy consumptions of construction equipment; and (3) disposal of construction wastes.

\subsection{Review of the calculation method of $G H G$ emissions}

There are various calculation methods available for calculating GHG emissions. By reviewing the previous studies, two key methods were found that are usually used for calculating GHG emissions. They are- process-based method and economic input-output analysis-based method. The processbased method mainly focuses on multiple activities related to a product or service. All materials and energy that are used for each activity in the entire process, are recognized and calculated. Thus, GHG emissions and overall environmental impacts can be determined responsible for the production of the materials and consumption of energy. Dimoudi and Tompa used the $\mathrm{CO}_{2}$ emission factors of typical building materials and calculated the $\mathrm{CO}_{2}$ emission for the manufacturing of building materials [1]. Yan et al. investigated emission for manufacturing building materials, energy consumption and disposal of construction wastes, and then calculated total GHG emissions in building construction for their case building in Hong Kong [6]. Gustavsson and Sathre [7] investigated the energy consumption of wood and concrete building materials and calculated the $\mathrm{CO}_{2}$ emission due to different types of energy; Chen et al. [8] calculated the energy consumption by using the embodied energy intensities for manufacturing building materials, transporting building materials and installing different types of building component. Gonza'lez and Navarro [9] also used this process-based method for calculating the $\mathrm{CO}_{2}$ emission due to building materials in their study.

The economic input-output analysis-based method focuses on the direct environmental impact of a product or service, as well as the indirect environmental impacts due to the supply chain. This method uses data from the Input/Output Table and assesses the environmental impacts in the construction industry. Suzuki et al. [10], Gerilla et al. [11] and Suzuki and Oka [12] used this method to calculate $\mathrm{CO}_{2}$ emission during building construction. Racoviceanu et al. [13], Pacca and Horvath [14] and Norman et al. [15] also calculated GHG emissions in construction and operation of 
water treatment systems, power plants and residential buildings respectively. Seo and Hwang [16] also calculated $\mathrm{CO}_{2}$ emission from residential buildings using this method.

\section{Methodology}

\subsection{Establishment of the calculation method of GHG emissions}

The economic input-output analysis-based method is adopted by many researchers from the USA and Japan. It is probably because of the Input/Output Table of the USA and Japan that covers more than 400 sectors, which is elaborate enough to evaluate the environmental impacts in the construction industry. But there is no available economic inputoutput data with resource and environmental output in Bangladesh, which is required by the economic input-output analysis-based method for the calculation of greenhouse gases. Therefore, the process-based method is used for calculating GHG emissions in this study.

\subsection{Working procedures}

After reviewing the works of literature, required information and measurements for the case building during the construction phase, have to be collected for the calculation of greenhouse gas emission. According to the process-based method, multiple activities related to the construction work of the case building are identified. The materials and energy required over the construction period by each of the identified activities are recognized and measured. Using the established calculation method, GHG emissions were calculated for each of the identified activities of the case building, individually or in total, due to building construction over the construction period. From the calculated value of GHG emissions, the calculation was analyzed and major contributing sources and materials were identified in order to provide proposals and strategies for the reduction of GHG emissions in building construction phase.

\subsection{System boundary}

This study is limited to the following processes: manufacture of building materials, transportation of building materials to construction site and disposal of construction wastes. The whole processes require energy to run during construction work and the GHG emission from the energy consumption of these processes is also considered.

\subsection{Sources of GHG emissions in this study}

From the literature review and our system boundary, three main sources of GHG emissions have been figured out in building construction. They are as follows: manufacture and transportation of building materials; energy consumption by construction equipment; and disposal of construction wastes incurred in the work. These main sources of GHG emissions were divided into six parts, shown in Fig. 1, for the ease of calculation. They are:

a) Embodied GHG emissions due to the manufacture of building materials;

b) GHG emissions from transportation for building materials;

c) GHG emissions from fuel combustion of construction equipment;

d) GHG emissions due to electricity used for construction equipment;

e) GHG emissions from fuel combustion of transportation for construction waste; and

f) GHG emissions from burning of wooden wastes.

\subsection{Calculation methods of GHG emissions in building construction}

\subsubsection{Embodied GHG emissions of building materials}

Embodied GHG emissions mainly occur due to the production of the building materials before transporting to the construction site and the value of emission differs by materials. Different materials show different embodied energy and cause different GHG emission values. Eq. (1) was used for calculating embodied GHG emissions of the materials. 


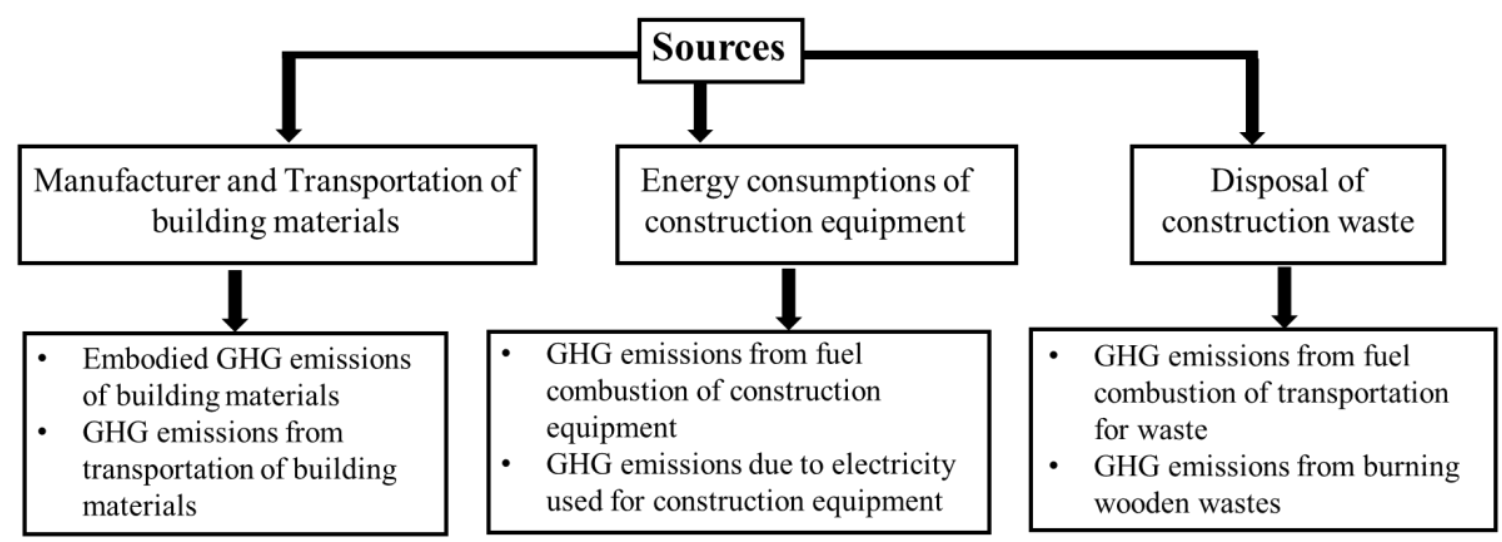

Fig.1 Sources of GHG emission.

$\mathrm{E}_{1}=\sum \mathrm{M}_{1} \times \mathrm{EF}_{1} / 1000$

Where, $\mathrm{E}_{1}$ is the total embodied GHG emissions of all building materials (in tons $\mathrm{CO}_{2}$-e $)\left(\mathrm{CO}_{2}\right.$-e: $\mathrm{CO}_{2}$ equivalent); $\mathrm{M}_{1}$ is the amount of particular building material (in $\mathrm{kg}$ ) and $\mathrm{EF}_{1}$ is the $\mathrm{GHG}$ emission factor for that building material (in $\mathrm{kg} \mathrm{CO}_{2}-\mathrm{e} / \mathrm{kg}$ ).

3.5.2. GHG emissions from transportation for building materials

This part calculates the GHG emissions due to the transportation of building materials, which are GHG emissions due to fuel and energy consumption for transporting building materials to construction sites, using Eq. (2).

$\mathrm{E}_{2}=\sum \mathrm{M}_{2} \times\left(\mathrm{T}^{1} \times \mathrm{EF}_{2}^{\mathrm{l}}+\mathrm{T}^{\mathrm{s}} \times \mathrm{EF}^{\mathrm{s}}{ }_{2}\right) / 1000$

Where, $E_{2}$ is the total GHG emissions from fuel combustion of transportation for all building materials (in tons $\mathrm{CO}_{2}$-e); $\mathrm{M} 2$ is the amount of a particular building material (in tons); $\mathrm{T}^{\mathrm{l}}$ is the total distance of transportation for that building material by land (in $\mathrm{km}$ ), while $\mathrm{T}^{\mathrm{s}}$ is the total distance of transportation for that building material by sea (in $\mathrm{km}$ ); and $\mathrm{EF}_{2}^{\mathrm{l}}$ is the GHG emission factor for transportation by land (in $\mathrm{kg} \mathrm{CO}_{2}$-e/ton-km), while $\mathrm{EF}^{\mathrm{s}}{ }_{2} \mathrm{GHG}$ emission factor for transportation by sea (in $\mathrm{kg} \mathrm{CO}_{2}$-e/ton-km).

3.5.3. GHG emissions from fuel combustion of construction equipment

Fuel and electricity contribute prodigious to the GHG emissions as the energy sources of construction equipment used in the construction work. Eq. (3) was used for the calculation of the GHG emissions in this part.

$\mathrm{E}_{3}=\sum \mathrm{M}_{3} \times \mathrm{EF}_{3} / 1000$

Where, $\mathrm{E}_{3}$ is the total GHG emissions from fuel combustion of construction equipment (in tons $\left.\mathrm{CO}_{2}-\mathrm{e}\right) ; \mathrm{M}_{3}$ is the amount of fuel consumed by construction equipment (in liters) and $\mathrm{EF}_{3}$ is the GHG emission factor for fuel consumed by construction equipment (in $\mathrm{kg} \mathrm{CO}_{2}$-e/liter).

\subsubsection{GHG emissions due to electricity used by construction equipment}

Eq. (4) was used to calculate the GHG emissions due to electricity used by the construction equipment.

$\mathrm{E}_{4}=\sum \mathrm{M}_{4} \times \mathrm{EF}_{4} / 1000$

Where, $\mathrm{E}_{4}$ is the total GHG emissions due to electricity used by construction equipment (in tons $\left.\mathrm{CO}_{2}-\mathrm{e}\right) ; \mathrm{M}_{4}$ is the quantity of purchased electricity from power company (in $\mathrm{kWh}$ ); and $\mathrm{EF}_{4}$ is the emission factor for that power company (in $\mathrm{kg} \mathrm{CO}_{2}-$ $\mathrm{e} / \mathrm{kWh}) ; \mathrm{EF}_{4}$ also has specific emission factor provided by its respective local provider of electricity (Power Development Board of Bangladesh in this case). 
3.5.5. GHG emissions from fuel combustion of transportation for construction waste

The emissions in construction waste disposal period are mostly generated by the transportation of demolition wastes to the disposal site. Eq. (5) was used to calculate the GHG emissions from fuel combustion of transportation for construction waste.

$\mathrm{E}_{5}=\sum \mathrm{M}_{5} \times \mathrm{T}_{\mathrm{d}} \times \mathrm{EF}_{5} / 1000$

Where, $E_{5}$ the total GHG emissions from fuel combustion of transportation for construction waste (in tons $\mathrm{CO}_{2}-\mathrm{e}$ ); $\mathrm{M}_{5}$ is the amount of waste transported to landfill (in tons); $\mathrm{T}_{\mathrm{d}}$ is the double distance between construction site and landfill (in $\mathrm{km}$ ); and $\mathrm{EF}_{5}$ is the GHG emission factor for transportation (in $\mathrm{kg} \mathrm{CO}_{2}$-e/ton-km), which can be evaluated as 0.159 , shown in Table 1 .

3.5.6. GHG emissions from burning of wooden wastes

Eq. (6) was used to calculate the GHG emissions from burning of wooden waste.

$\mathrm{E}_{6}=\sum \mathrm{M}_{6} \times \mathrm{EF}_{6} / 1000$

Where, $\mathrm{E}_{6}$ the total GHG emissions from burning of wooden wastes produced during construction period (in tons $\mathrm{CO}_{2}-\mathrm{e}$ ); $\mathrm{M}_{6}$ is the amount of wooden waste (in tons); The energy content in wood is assumed to be $15.8 \mathrm{MJ} / \mathrm{kg}$, which gives a $\mathrm{CO}_{2}$ emission of $32 \mathrm{~g} \mathrm{CO}_{2} / \mathrm{MJ}$ wood [17]. With the help of referenced data, the calculation of the emission factor, $\mathrm{EF}_{6}$ for wooden material after demolition, will give a result of $0.508 \mathrm{~kg} \mathrm{CO}_{2} / \mathrm{kg}$ wood.

\section{Case study: SWC building}

\subsection{Description of case building}

In order to implement the calculation methods for calculating GHG emissions on a practical case, Student Welfare Centre (SWC) building is chosen, which is located at the area of Khulna University of Engineering and Technology (KUET) in Khulna, Bangladesh. It is an institutional building, of which the construction period was from February 2014 to February 2017. It is an RC (reinforced concrete) framed building, covering a building area of 9875 $\mathrm{m}^{2}$ (the total gross floor area is $13427 \mathrm{~m}^{2}$ ).

More description of the case building is given in Table 2. The regarding information available of the case building was investigated over the entire construction period.

Table 1. GHG Emission factors for transportation of building materials

\begin{tabular}{llllll}
\hline $\begin{array}{l}\text { Transportation } \\
\text { method }\end{array}$ & $\begin{array}{l}\text { Energy use } \\
(\mathrm{MJ} / \text { ton-km) }\end{array}$ & Fuel type & $\begin{array}{l}\text { Quantity of } \\
\text { materials } \\
\text { (tons) }\end{array}$ & $\begin{array}{l}\text { Fuel GHG } \\
\text { emission factor } \\
\left(\mathrm{kg} \mathrm{CO}_{2} \text {-e/MJ) }\right.\end{array}$ & $\begin{array}{l}\text { GHG emission } \\
\text { factor }\left(\mathrm{kg} \mathrm{CO}_{2-}\right. \\
\text { e/ton-km })^{\mathrm{b}}\end{array}$ \\
\hline $\begin{array}{l}\text { By truck } \\
\text { By ship }\end{array}$ & 2.275 & Diesel & 24446.930 & 0.070 & 0.159 \\
\hline
\end{tabular}

${ }^{\mathrm{a}}$ Reference [6].

${ }^{\mathrm{b}} \mathrm{GHG}$ emission factor (in $\mathrm{kg} \mathrm{CO}$-e/ton $\left.\mathrm{km}\right)=$ Energy use $($ in $\mathrm{MJ} /$ ton $\mathrm{km}) \times$ Fuel GHG emission factor $\left(\mathrm{kg} \mathrm{CO}_{2}\right.$-e/MJ).

Table 2. Project description of SWC building

\begin{tabular}{ll}
\hline Items & Value \\
\hline Building Site Location & Khulna, Bangladesh \\
Scope of work & Office+Facility \\
Structure & RC (Reinforced Concrete) \\
Size & 3 stories above ground (up to $12 \mathrm{~m})$ \\
Construction Area & 9875 sq. m. \\
Gross Floor Area & 13427 sq. m. \\
Construction Cost & $148,920,418$ BDT \\
\hline
\end{tabular}




\subsection{Data collection}

Actual measurements and quantity of used materials, amount of fuels and electricity used during the construction phase, as well as other related data were collected for the purpose of this study. In order to collect those data, the authors sought assistance and collaboration among client, contractor, suppliers and other stakeholders of the case building. The acted authority for the case building was also interviewed and field investigations were conducted.

After all the interviews and collaboration, and proper field investigations, all the required data was collected from numerous sources. Superiority was defined for each of the data sources used, to ensure the accuracy of our collected data. The data sources and their corresponding superiority are shown in Table 3.

\subsection{Scope of the account}

The scope of the account for this study covered the carbon impacts regarding all the major activities during the construction period as well as the emissions from fuel (diesel in this case) and electricity used and embodied emissions from materials used in construction.

The major materials were considered in this case, which have the higher quantity value. Such as concrete, cement, sand, reinforced steel, brickwork, door frames/panels and glass. The amounts of considered materials are shown in Table 4.

Table 3. Data sources and the corresponding superiority

\begin{tabular}{ll}
\hline Data sources & Superiority Value \\
\hline Office receipt (i.e. diesel purchase bill, electricity purchase bill) & 1 \\
Stakeholders' report (i.e. material supply report) & 2 \\
Bill of Quantity (BOQ) & 3 \\
Material use record & 4 \\
Consultancy with contractor and supplier & 5 \\
\hline
\end{tabular}

Table 4. Building material list of SWC building

\begin{tabular}{l|lllll}
\hline Material & Specific element & $\begin{array}{l}\text { Volume } \\
\left(\mathrm{m}^{3}\right)^{\mathrm{a}}\end{array}$ & $\begin{array}{l}\text { Unit } \\
\text { weight } \\
\left(\mathrm{kg} / \mathrm{m}^{3}\right)\end{array}$ & $\begin{array}{l}\text { Quantity } \\
(\text { tons })\end{array}$ & $\begin{array}{l}\text { GHG emission factor } \\
\left(\mathrm{kg} \mathrm{CO}_{2}-\mathrm{e} / \mathrm{kg}\right)\end{array}$ \\
\hline $\begin{array}{l}\text { Concrete } \\
\text { Sand }\end{array}$ & Concrete & 5937.049 & 2400 & 14248.917 & 0.170 \\
Cement & Sand & 4929.825 & 1600 & 7887.720 & 0.0074 \\
Reinforced bars & Cement, dry & 130.393 & 1440 & 187.765 & 1.035 \\
& $\begin{array}{l}\text { Steel, reinforced, } \\
\text { virgin }\end{array}$ & & 7850 & 466.458 & 1.330 \\
& $\begin{array}{l}\text { Steel, reinforced, } \\
\text { recycled }\end{array}$ & & & & 0.337 \\
$\begin{array}{l}\text { Glass } \\
\begin{array}{l}\text { Door } \\
\text { frames/panels }\end{array}\end{array}$ & Glass, float & 51.251 & 2500 & 128.127 & 1.858 \\
$\begin{array}{l}\text { Brick-work } \\
\text { Total }\end{array}$ & Brick & 9.551 & 400 & 3.820 & -1.141 \\
\hline
\end{tabular}

${ }^{\text {a }}$ Superiority value is 4 . 


\subsection{Transportation}

GHG emissions from the transportation of building materials to the construction site and the transportation of construction wastes to the disposal site, both were considered in this study. All the materials considered in this study were transported by land (truck in this case) from their manufacturing factories.

The distances from the manufacturing locations of the materials to the construction site were shown in Table 5. In addition, the construction wastes incurred during the work period were dumped in a location, with a distance of $7 \mathrm{~km}$ from the construction site. Therefore, the double distance of the disposal site from the construction site will be $14 \mathrm{~km}$.

\subsection{Energy consumption}

GHG emissions from energy consumption by the construction equipment and the vehicles (truck in this case) used due to the transportation of building materials and construction wastes were considered in this study. In the case of the targeted building, the construction equipment consumed diesel as fuel over the entire construction period.

Energy consumption refers to fuel consumption and electricity used for multiple works, shown in Table 6. The building is located at Khulna division in Bangladesh, where the electricity supply mainly depends on diesel-based production, as the Power Development Board of Bangladesh (PDB), the local electricity provider uses diesel for the production of electricity for that area. The PDB values the emission factor as 0.62 , required to calculate the GHG emissions due to electricity used by construction equipment.

Table 5. Country of origins of building materials of SWC building

\begin{tabular}{llll}
\hline Materials & Country of origin & \multicolumn{2}{c}{ Distance from site $(\mathrm{km})^{\mathrm{b}}$} \\
\cline { 3 - 4 } & & Land & Sea \\
\hline Concrete & On-site & 0 & 0 \\
Sand & Kushtia, Bangladesh & 171 & 0 \\
Cement & Mongla, Bangladesh & 57.7 & 0 \\
Steel, reinforced (virgin) & Chittagong, Bangladesh & 522 & 0 \\
Glass & Gazipur, Bangladesh & 315 & 0 \\
Door frames/panels & Khulna, Bangladesh & 5.5 & 0 \\
Brick-work & Khulna, Bangladesh & 4.1 & 0 \\
Total distance & & 1075.30 &
\end{tabular}

${ }^{\text {a }}$ Superiority value is 3 .

${ }^{\mathrm{b}}$ This is an average distance measured from Google Maps.

Table 6. Energy consumption and waste production of SWC building

\begin{tabular}{llll}
\hline Year & Electricity $(\mathrm{kWh})^{\mathrm{a}}$ & Diesel (liter $)^{\mathrm{a}}$ & Waste (tons) $^{\mathrm{b}}$ \\
\hline 2014 & 38800 & 1500 & 0.524 \\
2015 & 42016 & 1680 & 1.775 \\
2016 & 55320 & 1144 & 0.903 \\
\hline
\end{tabular}

${ }^{\text {a }}$ Superiority value is 1 .

${ }^{\mathrm{b}}$ Superiority value is 5 . 


\section{Calculation of GHG emissions}

\subsection{Total GHG emissions}

The amount of total GHG emissions will show how much greenhouse gas was emitted for the targeted building over its entire construction period. In order to control the emissions, this calculation will help us a lot to take efficient steps in the future.

Using the equations from (1) to (6) stated above, GHG emissions from six parts can be calculated and by summing them up, the total GHG emissions due to the construction of SWC building can be exposed, shown in Table 7.

\subsection{GHG emission intensity}

Table 7 shows the total GHG emission of the referenced building which is 7257.104 tons $\mathrm{CO}_{2}$-e and the total gross floor area for the building is 13427 sq. m. Hence, the result for the intensity of total GHG emission for SWC building gives a value of $540.48 \mathrm{~kg} \mathrm{CO}_{2}-\mathrm{e} / \mathrm{m}^{2}$, which is pretty much usual.

Comparing to the results of intensity of GHG emissions from other buildings, listed in Table 8, the result of calculated intensity of GHG emissions with a value of $540.48 \mathrm{~kg} \mathrm{CO}_{2}-\mathrm{e} / \mathrm{m}^{2}$ for the $\mathrm{SWC}$ building (RC structure, F3, GFA value of 13,427 $\mathrm{m}^{2}$ ), seems to be reasonable.

\section{Results and discussions}

\subsection{Analysis of results}

The results indicate that the two major parts contributing to the total GHG emissions are the embodied GHG emissions and the transportation of building materials to the construction site. About $94.77 \%$ of the total GHG emissions are for the embodied GHG emissions, and $3.61 \%$ are from the transportation; $1.31 \%$ of the total GHG emissions are due to the energy consumption of construction equipment, where $0.15 \%$ from fuel combustion of construction equipment and $1.16 \%$ from the electricity used by construction equipment; $0.03 \%$ are due to disposal of construction waste; and only $0.28 \%$ are due to burning of wooden wastes.

In the sector of embodied GHG emissions, concrete and brick-work are the two major materials causing an excessive embodied GHG emissions, about $86.89 \%$ of the total embodied GHG emissions. From Fig. 2, it can be seen that $35.22 \%$ of the total embodied GHG emission is for concrete, $48.67 \%$ for brick-work, $9.02 \%$ for steel, $3.46 \%$ for glass, $2.82 \%$ for cement and only $0.84 \%$ for sand. Whereas door frames/panels contribute a negative percentage of $0.06 \%$ of the total emission, therefore it reduces the total emission of the building.

Table 7. Total GHG emissions in the construction of SWC building (in tons $\mathrm{CO}_{2}$-e)

\begin{tabular}{lllll}
\hline Parts & $\begin{array}{l}\text { GHG emissions } \\
\text { (virgin materials) }\end{array}$ & Percentage & $\begin{array}{l}\text { GHG emissions } \\
\text { (recycled materials) }\end{array}$ & Percentage \\
\hline $\mathrm{E}_{1}$ & 6877.691 & $94.77 \%$ & 6432.80 & $94.43 \%$ \\
$\mathrm{E}_{2}$ & 262.253 & $3.61 \%$ & 262.253 & $3.85 \%$ \\
$\mathrm{E}_{3}$ & 11.315 & $0.15 \%$ & 11.315 & $0.16 \%$ \\
$\mathrm{E}_{4}$ & 84.404 & $1.16 \%$ & 84.404 & $1.24 \%$ \\
$\mathrm{E}_{5}$ & 1.121 & $0.03 \%$ & 1.121 & $0.02 \%$ \\
$\mathrm{E}_{6}$ & 20.321 & $0.28 \%$ & 20.321 & $0.30 \%$ \\
Total & 7257.104 & $100.00 \%$ & 6812.213 & $100.00 \%$ \\
\hline
\end{tabular}

Table 8. GHG emissions intensity in building constructions (in $\mathrm{kg} \mathrm{CO}_{2}-\mathrm{e} / \mathrm{m}^{2}$ )

\begin{tabular}{llllllc}
\hline No. & Building type & Structure & $\mathrm{GFA}\left(\mathrm{m}^{2}\right)$ & Storeys & $\mathrm{kg} \mathrm{CO}_{2}-\mathrm{e} / \mathrm{m}^{2}$ & Sources \\
\hline 1 & Residential & $\mathrm{SRC}$ & 10,339 & $\mathrm{~F} 20+\mathrm{B} 1$ & 715 & {$[9]$} \\
2 & Office & $\mathrm{RC}$ & 1857 & $\mathrm{~F} 7+\mathrm{B} 1$ & 650 & {$[9]$} \\
3 & Institutional & $\mathrm{RC}$ & 400 & $\mathrm{~F} 3$ & 386 & {$[1]$} \\
\hline
\end{tabular}



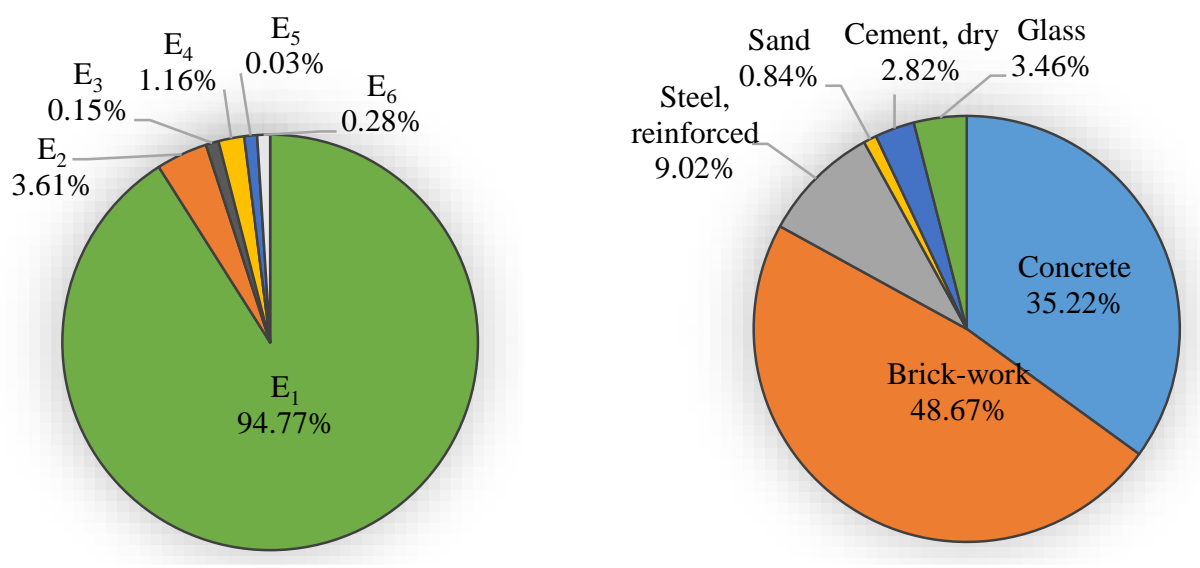

Fig. 2 Contributing factors in total GHG emissions of SWC building.

\subsection{Reduction of $G H G$ emissions for this case}

It is clear that 7257.104 tons of $\mathrm{CO}_{2}$-e is a huge value for $\mathrm{GHG}$ emissions in the term of environmental safety, in which embodied energy of building materials contributes the most portion $(94.77 \%)$. Energy consumption during manufacture can provide an approximate indication of the environmental impact of the material, and for most building materials, the major environmental impacts occur during the preliminary processes. Lightweight building materials can be a solution as it offers lower embodied energy than heavyweight materials, but in certain cases, lightweight construction may require in higher energy use. For instance, this may increase the overall energy use of the entire building where the requirements of heating and cooling are high.

\subsubsection{Using recycled steel}

Recycling existing steel is cheaper and more environment-friendly than mining for iron and replica watches through the manufacturing process of steel. According to the report of World Steel Association, it is estimated that about 2 billion tonnes of iron ore, 1 billion tonnes of metallurgical coal and 575 million tonnes of recycled steel were used by the global steel industry to produce about 1.7 billion tonnes of crude steel. In order to produce a tonne of pig iron, it takes typically 1.6 tonnes of iron ore and around $450 \mathrm{~kg}$ of coke (Raw Materials,
World Steel Association, 2019). Recycling 1 ton of steel can save about 1.1 tons of iron ore, $630 \mathrm{~kg}$ of coal and $55 \mathrm{~kg}$ of limestone, as well as the energy savings due to the less manufacturing process than virgin steel. The information provided by the stakeholders' report with a superiority value 2, made us known that the reinforced steel used for the construction of the case building is virgin.

In the case of the referenced building, shown in Table 9, using recycled steel instead of virgin steels could reduce the GHG emission from 620.74 tons of $\mathrm{CO}_{2}$-e to 175.85 tons of $\mathrm{CO}_{2}$-e, a reduction of $72 \%$, caused by the material. This results directly affect the total embodied emission and overall GHG emission of the building, with a reduction of $6.47 \%$ and $4 \%$ respectively.

\subsubsection{Changing transportation method}

Changing the transportation method of building materials from by truck to by ship can help effectively for the reduction of GHG emissions, as the fuel used for ships (i.e. heavy fuel oil) uses much less energy per ton-km than diesel does, shown in Table 1. This is why the emission factor for the ship transportation method is lesser than the truck transportation method.

Table 10 shows the quantity of GHG emission for the same amount of materials transported by both truck and ship, as well as the same distance from the project site, in order to compare the results between them. 
Table 9. Embodied GHG emission of building materials used for SWC building

\begin{tabular}{|c|c|c|c|c|c|}
\hline Material & $\begin{array}{l}\text { Quantity } \\
\text { (tons) }\end{array}$ & $\begin{array}{l}\text { GHG emission } \\
\text { (virgin materials) } \\
\text { (in tons } \mathrm{CO}_{2}-\mathrm{e} \text { ) }\end{array}$ & Percentage & $\begin{array}{l}\text { GHG emission } \\
\text { (recycled } \\
\text { materials) } \\
\text { (in tons } \mathrm{CO}_{2}-\mathrm{e} \text { ) }\end{array}$ & Percentage \\
\hline Concrete & 14248.917 & 2422.68 & $35.22 \%$ & 2422.68 & $37.67 \%$ \\
\hline $\begin{array}{l}\text { Steel, } \\
\text { reinforced }\end{array}$ & 466.458 & 620.74 & $9.02 \%$ & 175.85 & $2.71 \%$ \\
\hline Sand & 7887.720 & 58.30 & $0.84 \%$ & 58.30 & $0.90 \%$ \\
\hline Cement, dry & 187.765 & 194.36 & $2.82 \%$ & 194.36 & $3.02 \%$ \\
\hline Glass & 128.127 & 238.05 & $3.46 \%$ & 238.05 & $3.72 \%$ \\
\hline $\begin{array}{l}\text { Door } \\
\text { frames/panels }\end{array}$ & 3.820 & -4.36 & $-0.06 \%$ & -4.36 & $-0.06 \%$ \\
\hline Brickwork & 1524.123 & 3347.92 & $48.67 \%$ & 3347.92 & $52.04 \%$ \\
\hline Total & 24446.93 & 6877.69 & $100.00 \%$ & 6432.80 & $100.00 \%$ \\
\hline
\end{tabular}

Table 10. Reduction of GHG emissions due to transportation of building materials

\begin{tabular}{llllll}
\hline $\begin{array}{l}\text { Transportation } \\
\text { Method }\end{array}$ & Fuel Type & $\begin{array}{l}\text { Quantity of } \\
\text { materials } \\
\text { transported } \\
\text { (tons) }\end{array}$ & $\begin{array}{l}\text { Distance } \\
\text { from site } \\
(\mathrm{km})^{\mathrm{a}}\end{array}$ & $\begin{array}{l}\text { GHG emission } \\
\text { factor }\left(\mathrm{kg} \mathrm{CO} 2^{-}\right. \\
\text {e/ton-km) }\end{array}$ & $\begin{array}{l}\text { GHG Emission } \\
\left.\text { (in tons } \mathrm{CO}_{2}-\mathrm{e}\right)\end{array}$ \\
\hline $\begin{array}{l}\text { By truck } \\
\text { By ship }\end{array}$ & $\begin{array}{l}\text { Diesel } \\
\text { Heavy fuel } \\
\text { oil }\end{array}$ & 24446.93 & 1075.30 & 0.159 & 262.253 \\
\hline
\end{tabular}

a Total distance to the construction site from multiple manufacturing sources of different used materials is $1075.30 \mathrm{~km}$, shown in Table 5.

\subsubsection{Changing fuel type}

Construction equipment, as well as the transportation system for building materials and waste disposal, use lots of fuel as an energy source emitting huge emission to the environment during the construction period. In the case of the targeted building, diesel was used to meet the demand for fuel over the construction period. By adopting lower-emitting fuel such as gasoline can help much in this regard.

Table 11 shows that the GHG emissions due to diesel use caused 262.253 tons of $\mathrm{CO}_{2}$-e, where gasoline would cause 3983.565 tons of $\mathrm{CO}_{2}$-e. That means, if gasoline was replaced in place of diesel, it would cause $5 \%$ less GHG emissions than the previous.
6.2.4. Using hardwood plywood for partition walls The SWC building is an RC-based structure where all the construction walls are non-load bearing walls or partition walls. The GHG emission due to the brick-work for these partition walls is much higher, which is valued a quantity of 3347.92 tons of $\mathrm{CO}_{2}$ e, contributing the largest portion (48.67\%) for embodied GHG emissions.

For the reduction, in this case, hardwood plywood can be used in place of those construction walls. Hardwood plywood is an environment-friendly and much lesser emitter of GHG emission, providing excellent strength, stiffness and resistance to creep, comparing to the traditional brick walls. Energy requirements within the mechanical plywood-based industry are shown in Table 12 and the value of GHG emissions due to the manufacture of both materials, hardwood plywood and brick walls is shown in Table 13. 
Table 11. Reduction of GHG emissions due to fuel use

\begin{tabular}{lll}
\hline Purpose of use & $\begin{array}{l}\mathrm{GHG} \text { emission (in tons } \mathrm{CO}_{2-} \\
\text { e) (using diesel) }\end{array}$ & $\begin{array}{l}\text { GHG emission (in tons } \mathrm{CO}_{2-} \\
\text { e) (using gasoline) }\end{array}$ \\
\hline $\begin{array}{l}\text { Consumption for transporting building } \\
\text { materials (by-truck) }\end{array}$ & 262.253 & 249.097 \\
$\begin{array}{l}\text { Consumption by construction } \\
\text { equipment }\end{array}$ & 11.315 & 10.642 \\
$\begin{array}{l}\text { Consumption for waste disposal } \\
\text { Total }\end{array}$ & 1.121 & 1.064 \\
\hline
\end{tabular}

Table 12. Energy requirements within the mechanical plywood-based industry according to FAO (Food and Agriculture Organization of the United Nations) Forestry Paper, 1990 [12]

\begin{tabular}{lll}
\hline Materials & \multicolumn{2}{l}{ Energy Requirements for manufacturing } \\
& Electrical $\left(\mathrm{kWh} / \mathrm{m}^{3}\right)$ & Motor Fuel $\left(1 / \mathrm{m}^{3}\right)$ \\
\hline Hardwood plywood & 230 & 4 \\
Softwood plywood & 150 & 3 \\
\hline
\end{tabular}

Table 13. Total embodied GHG emissions calculated for hardwood plywood and brick walls

\begin{tabular}{ccc}
\hline Materials & $\begin{array}{c}\text { Volume of materials } \\
\left(\text { in } \mathrm{m}^{3} \text { ) }\right.\end{array}$ & $\begin{array}{c}\text { Total Embodied GHG emissions } \\
\text { (in tons } \mathrm{CO}_{2} \text {-e) }\end{array}$ \\
\hline Hardwood plywood & 952.577 & 145.801 \\
Brick walls & 952.577 & 3347.920 \\
\hline
\end{tabular}

The volume of the built construction walls of the referenced building is used in this comparison. The result indicates that using hardwood plywood instead of traditional brick-walls could cause a massive, $95.6 \%$ less GHG emission to the environment, for the referenced building. If it is not possible to use hardwood plywood in place of brick walls for all the walls of a building, it is suggested that hardwood plywood should be used as much as possible to reduce GHG emissions in an efficient way.

\subsubsection{Re-Using wooden waste materials}

In addition to these, re-using wooden waste materials in new buildings is preferable to burning them or disposing them into disposal sites. From Table 7, it can be seen that the quantity of GHG emission from burning the wooden waste materials is much lower than other parts, valuing 20.321 tons of $\mathrm{CO}_{2}$-e, but has a contributing portion to the emission. Wooden wastes should be handled carefully after use, as the efficiency of wooden materials for reducing GHG emissions depends not only on variations in the manufacturing process of that product but also on how the wooden wastes are handled. The GHG emission will be slightly positive if all the wooden wastes are used to replace fossil fuels by burning them, while the GHG emission will be negative if they are re-used and clearly positive if they are deposited into the soil [17]. However, it is not possible to re-use all the wood products in a building, due to technical and economic limitations. But it is assumed that half of the wooden construction materials can be re-used in a new building [1], causing a less emission value of 10.161 tons of $\mathrm{CO}_{2}$-e for this case due to burning of wooden wastes, as well as leading to a reduction in energy use in the production of new building materials of $50 \%$, while the other half is used to replace fossil fuels.

\subsubsection{Overall reduction of emission for this case}

In this study, five specific strategies are proposed for the reduction of GHG emissions calculated for 
this case building. If these strategies would be followed strictly, then the emissions due to the construction of the case building could be reduced by $44.46 \%$, shown in Table 14 .

\section{Conclusion}

In the recent few years, GHG emissions have pulled great attention from the world community because of its harmful and devastating effects on the environment. As a result, many recent studies are focusing on the construction industries to control the GHG emissions emitted from construction processes. This very imperative topic has been prioritized in this study. The focus of this study is to identify the sources of GHG emissions in building construction and the sources aremanufacture and transportation of building materials, energy consumption of different construction equipment and disposal of construction waste. These three major sources were categorized into six subparts and then followed the calculation method of each part. These six parts aremanufacture of building materials, transportation of building materials to the construction site, fuel used by the construction equipment, electricity used by the construction equipment, transportation of construction wastes to the disposal site and burning of wooden wastes in the disposal site.
Analyzing the results, shown in Figure 2, what have been attained from the calculation of GHG emissions in the construction of the case building, it is found that almost $98.38 \%$ of the total GHG emissions in building construction come from manufacture and transportation of building materials, wherein $94.77 \%$ are from the embodied GHG emissions of building materials and $3.61 \%$ are from the transportation for building materials. Energy consumption by construction equipment has caused almost $1.31 \%$ of total emissions, which is very less amount compared to the manufacture and transportation of building materials. Then again, disposal of construction waste causes only $0.31 \%$ of total GHG emissions, wherein $0.03 \%$ for transportation of wastes to the disposal site and $0.28 \%$ from burning wooden wastes. Furthermore, analyzing the results for the building materials, $35.22 \%$ of the total embodied GHG emission is for concrete; $48.67 \%$ for brick-work, which is the highest; $9.02 \%$ for steel; $3.46 \%$ for glass; $2.82 \%$ for cement and only $0.84 \%$ for sand. Whereas door frames/panels contribute a negative percentage of $0.06 \%$ of the total emission as it reduces its surrounding emission.

In addition to the above, for the reduction of GHG emissions for the case of SWC building, some specific steps have been specified that can be followed to achieve the purpose.

Table 14. Overall reduction of GHG emissions for SWC building applying the proposed strategies

\begin{tabular}{|c|c|c|c|c|}
\hline Parts & $\begin{array}{l}\mathrm{GHG} \text { emission (in tons } \\
\left.\mathrm{CO}_{2}-\mathrm{e}\right) \text { (actual) }\end{array}$ & Percentage & $\begin{array}{l}\text { GHG emission (in tons } \mathrm{CO}_{2}-\mathrm{e} \text { ) } \\
\text { (applying strategies) }\end{array}$ & Percentage \\
\hline $\mathrm{E}_{1}$ & 6877.691 & $94.77 \%$ & $3675.572^{\mathrm{a}}$ & $91.18 \%$ \\
\hline $\mathrm{E}_{2}$ & 262.253 & $3.61 \%$ & $249.097^{b}$ & $6.18 \%$ \\
\hline $\mathrm{E}_{3}$ & 11.315 & $0.15 \%$ & $10.642^{c}$ & $0.27 \%$ \\
\hline $\mathrm{E}_{4}$ & 84.404 & $1.16 \%$ & 84.404 & $2.09 \%$ \\
\hline $\mathrm{E}_{5}$ & 1.121 & $0.03 \%$ & $1.064^{\mathrm{d}}$ & $0.03 \%$ \\
\hline $\mathrm{E}_{6}$ & 20.321 & $0.28 \%$ & $10.161^{\mathrm{e}}$ & $0.25 \%$ \\
\hline Total & 7257.104 & $100.00 \%$ & 4030.940 & $100.00 \%$ \\
\hline
\end{tabular}

\footnotetext{
${ }^{a}$ Using recycled steel materials and hardwood plywoods.

${ }^{\mathrm{b}}$ Using gasoline in place of diesel for transportation of building materials.

${ }^{\mathrm{c}}$ Using gasoline as fuel for the construction equipment.

${ }^{\mathrm{d}}$ Using gasoline as fuel for transportation of disposal wastes.

e Assuming that $50 \%$ of the wooden wastes could be used for the production of new buildings.
} 
By comparing of GHG emissions from manufacture of virgin reinforced steel and those from manufacture of recycled reinforced steel in the case of SWC building, it has been found that embodied GHG emissions of concrete and brick-works account for $83.89 \%$ of the emissions from all building materials; and using recycled building materials, specially reinforced steel, could decrease the total GHG emissions by a considerable amount, about $4 \%$ in this case. Changing transportation method for building materials from by-truck to byship, it could lessen $89.63 \%$ of total GHG emissions, whereas changing fuel type from diesel to gasoline could help the total GHG emissions decrease by almost 5\%, for this case. Finally, using hardwood plywood in place of non-load bearing brick walls or partition walls of the referenced building could cut $95.6 \%$ of GHG emissions caused by that specific material and $44.12 \%$ of total GHG emissions. But in the practical case, if it is not possible to transport all the building materials by ships instead of trucks then it is suggested to transport the building materials as much as possible.

The result indicates that, by using recyclable building materials, transporting building materials by sea, re-using wooden waste materials, using hardwood plywood in place of non-load bearing brick walls and adopting energy-saving construction technology, GHG emissions can be reduced in building construction to a significant degree. Emphasizes should be put on the construction management strategies in construction equipment use, human activities and transportation. Meanwhile, prefabrication components and materials are highly recommended to improve the environmental benefits of GHG emissions.

The research work is limited to the construction phase of buildings but in order to get total GHG emissions for the whole life cycle for a building, further research works should be conducted on the operation, maintenance and demolition stages, as these have not been conducted in this study. Besides, as per the proposed strategies in this study, it is not always practically possible to transport all the materials used for the construction by ship transportation or to use hardwood plywood in place of brick walls for all the walls of a building, so it is recommended to transport the materials by ship or to use hardwood plywood in walls as much as possible. If these introduced strategies will be followed strictly in the construction of buildings, greenhouse gas emissions will be decreased dramatically and we can be able to avoid global warming issues. The implication of this study is easy as the procedure for estimating greenhouse gas emissions in the construction phase is quite similar to all types of buildings. Values for different materials, fuels and different types of transportation methods have been included in this study and how to use these values in different conditions has been cleared in this study. So, the amount of greenhouse gas emissions can be easily calculated for several buildings following the estimation for the case building in this study.

\section{References}

[1] Dimoudi A, Tompa C (2008). Energy and environmental indicators related to construction of office buildings. Resources, Conservation and Recycling, 53(1-2), 86-95.

[2] Metz B, Davidson O, Bosch P, Dave R, Meyer L. Climate Change 2007: Mitigation. Cambridge University Press, 2007.

[3] Takano A, Pittau F, Hafner A, Ott S, Hughes M, De Angelis E (2014). Greenhouse gas emission from construction stage of wooden buildings. International Wood Products Journal, 5(4), 217 223.

[4] Shiel J (2009). Practical greenhouse gas reduction strategies for the existing building stock. Architectural Science Review, 52(4), 270-278.

[5] Freitas Jr JA, Sanquetta CR, Iwakiri S, Maron da Costa MdRdM (2018). The use of wood construction materials as a way of carbon storage in residential buildings in Brazil. International Journal of Construction Management, doi:10.1080/15623599.2018.1532384.

[6] Yan H, Shen GQP, Fan LCH, Wang Y, Zhang L (2010). Greenhouse gas emissions in building construction: A case study of One Peking in Hong Kong. Building and Environment, 45(4), 949-955.

[7] Gustavsson L, Sathre R (2006). Variability in energy and carbon dioxide balances of wood and 
concrete building materials. Building and Environment, 41(7), 940-951.

[8] Chen T, Burnett J, Chau C (2001). Analysis of embodied energy use in the residential building of Hong Kong. Energy, 26(4), 323-340.

[9] González MJ, Navarro JG (2006). Assessment of the decrease of $\mathrm{CO}_{2}$ emissions in the construction field through the selection of materials: Practical case study of three houses of low environmental impact. Building and Environment, 41(7), 902-909.

[10] Suzuki M, Oka T, Okada K (1995). The estimation of energy consumption and $\mathrm{CO}_{2}$ emission due to housing construction in Japan. Energy and Buildings, 22(2), 165-169.

[11] Gerilla G, Teknomo K, Hokao K (2007). An environmental assessment of wood and steel reinforced concrete housing construction. Building and Environment, 42(7), 2778-2784.

[12] Suzuki M, Oka T (1998). Estimation of life cycle energy consumption and $\mathrm{CO}_{2}$ emission of office buildings in Japan. Energy and Buildings, 28(1), 33-41.

[13] Racoviceanu AI, Karney BW, Kennedy CA, Colombo AF (2007). Life-cycle energy use and greenhouse gas emissions inventory for water treatment systems. Journal of Infrastructure Systems, 13(4), 261-270.

[14] Pacca S, Horvath A (2002). Greenhouse gas emissions from building and operating electric power plants in the Upper Colorado River Basin. Environmental Science \& Technology, 36(14), 3194-3200.

[15] Norman J, MacLean HL, Kennedy CA (2006). Comparing high and low residential density: lifecycle analysis of energy use and greenhouse gas emissions. Journal of Urban Planning and Development, 132(1), 10-21.

[16] Seo S, Hwang Y (2001). Estimation of $\mathrm{CO}_{2}$ emissions in life cycle of residential buildings. Journal of Construction Engineering and Management, 127(5), 414-418.

[17] Börjesson P, Gustavsson L (2000). Greenhouse gas balances in building construction: wood versus concrete from life-cycle and forest land-use perspectives. Energy Policy, 28(9), 575-588.

[18] Zhang X, Shen L, Zhang L (2013). Life cycle assessment of the air emissions during building construction process: A case study in Hong Kong. Renewable and Sustainable Energy Reviews, 17, 160-169. 